\title{
Primary Mediastinal (Thymic) Large B-Cell Lymphoma by Ann Arbor Stage
}

National Cancer Institute

\section{Source}

National Cancer Institute. Primary Mediastinal (Thymic) Large B-Cell Lymphoma by Ann

Arbor Stage. NCI Thesaurus. Code C141262.

An anatomic stage for mediastinal (thymic) large B-cell lymphoma based on the Ann Arbor classification criteria. 